\title{
Homegrown Democracy, Homegrown Democrats
}

\author{
Norman K. Denzin
}

Another political story, a narrative about political depression. We are 45 days out and counting from the 2004 election. Bush is leading Kerry in every poll. I despair. Nothing is working. Yesterday the New York Times devoted the entire Op Ed page to advice for the Kerry campaign. "Get a Message" seemed to be the message, and stay on it. Fifty percent of the American public think the country is headed in the wrong direction, and Bush is still leading Kerry by 13 points. The cracks in the history of this administration have been exposed. The Bush Presidency has trashed the environment, welfare, education, the economy, turned the rest of the world against us, and over 10,000 Iraqis and 1000 Americans have died in his dirty little Middle Eastern war. There are more than 100 anti-Bush books, and still counting. Bush's lies have been catalogued, documented and analyzed (Corn 2003; Dowd 2004; Ivins 2003; Moore 2003; Pope 2003; Powers 2003). There were no weapons of mass destruction. The Iraqis do not love us. Bush was warned in advance of 9/11. And yet none of this seems to matter. Bush's handlers have turned fantasy into reality. Sixty percent of the voters still think Saddam supported Al Qaeda.

Critics assert that George Bush is a liar, a "President who knowingly and deliberately twists facts for political gain" (Hersh 2004: 367; Corn 2003). Turning intelligence estimates and wishful thinking into statements of fact has become an art form in this administration. Even Karl Rove knew, if Bush didn't, that arguments about Saddam's WMD program were based on "estimates full of judgments, not absolute certainties" (Woodward 2004: 219). Indeed, Rove understands the difference between a fact and intelligence. Paraphrasing Woodward, "If it's a fact, it is not called intelligence" (Woodward 2004: 219).

But to call Bush a liar assumes that his lying indicates "an understanding of what is desired, what is possible, and how best to get there. A more plausible explanation is that words have no meaning for this President beyond the immediate moment, and so he believes that his mere utterance of the phrases makes them real. It is a terrifying possibility" (Hersh 2004: 367). Indeed!

The discourse about Bush's lying presumes that there is reality against which assertions of truth and lying can be judged. This is a contested assertion. In the postmodern age of simulation the hypperreal is more real than the real. Baudrillard (1983) taught us this. In such a regime, a lie is true if it conforms to the hypperreal; that is, if it has the appearance of truth. Bush and his handlers skillfully manipulate this postmodern logic, ensuring that his assertions about the real have the appearance of being truthful. Indeed the entire Iraqi war was premised on this model.

The public was sold the belief that WMDs existed in an empirical reality. The inspectors would be able to locate the weapons, even though Saddam claimed they did not exist. Indeed Saddam's lies proved the weapons existed. In the end the weapons did not need to be found. Their absence meant they existed. We had no choice but to go to war.

The media model that scripted Bush's war short-circuited history by manipulating the logic of the hypperreal. It created instant meaning by producing a fictional sense of public opinion which supported the war. Saddam and $\mathrm{Al}$ Queda were connected. Saddam was evil. Al Queda is evil. The war was making America safer from terrorists. A total 
mythological system was in place. A closed system where lies became truth, and truth became that which conformed to the hypperreal. And this is how we got into this mess.

Any attempt to checkmate this system by remaining within this structural communication grid is doomed to failure. Three thousand books proving that Bush is a liar will not alter the fact that we are in this war. The discourse about lies and truth is a dead-end.

In the face of all of this I turn to Arundhati Roy for wisdom and understanding. She speaks for me (2004: 41). We are living in a time of "Instant-Mix Imperial Democracy (bring to a boil, add oil, then bomb)" (Roy 2004: 47). "We are, "the people of the world, confronted with an Empire armed with a mandate from heaven...an Empire that has conferred upon itself the right to go to war at will and the right to deliver people from corrupting ideologies...by the age-old, tried-and-tested practice of extermination" (Roy 2004: 47).

This Empire cannot stand still. It "is on the move, and Democracy is its sly new war cry. Democracy, homedelivered to your doorstep, by daisy-cutters. Death is a small price for people to pay for the privilege of sampling this new product: Instant-Mix Imperial Democracy" (Roy 2004: 47).

Like many, I too am tired of "racing to keep abreast of the speed at which our freedoms are being snatched from us" (Roy 2004: 41). Who among us "can afford the luxury of retreating from the streets for a while in order to return with an exquisite, fully formed political thesis" (Roy, 2004: 41), apparently neither John Kerry, nor the Democratic party.

And so I felt a great excitement when I saw Garrison Keillor's new book, Homegrown Democrat (2004). I thought, here is a man who thinks deeply about democracy, and these troubling times we are living in. He'll pull me out of my depression. So I bought the book.

Keillor occupies a special place in my biography. Without fail, every Saturday at 5:00 p.m. I listen to A Prairie Home Companion. I love the folk music, and the jazz, Guy Noir, the stories from Lake Wobegon, the opening monologues, which have for the last four years frequently mocked George Bush. I love Keillor's 1960's sensibilities, his mid-life struggles with fatherhood, his wry humor, his efforts to find a comfortable place inside this neoconservative project called corporate globalization. I love his criticisms of the neo-cons, how they have molded the instruments of democracy, including an independent judiciary, a free press, and the right to vote to their own purposes (Keillor 2004: 3).

So I fixed a glass of iced tea, grabbed Homegrown Democracy and settled into a comfortable chair on my deck, basking in the late afternoon sun. Time for a little Lake Wobegon therapy. What is this thing Keillor calls homegrown democracy? It is surely not anything like Bush's "Instant-Mix Imperial Democracy," that home-delivered democracy that arrives with a war cry and a bomb. To my delight, I felt right at home. Keillor dedicates his book "to all of the good democratic-farmer laborites of Minnesota." These are my people, farmers from the heartland. Democrats.

Homegrown Democracy moves in three directions at the same time. It is a short version of Keillor's autobiogaphy. It is his attack on Bush, the Iraqi war, the neo-cons and conservative Republicans. It is his celebration of the values that mean-spirited Republicans, corporate shills, hobby cops, misanthropic frat boys, and gun fetishists have attacked. These are the homegrown democratic values of the hard-working, God-fearing people of Lake Wobegon, and their idea of the common good. The Republicans have broken the civic compact, the simple code of the Golden Rule that underlies Midwestern civility. The politics of kindness. The obligation to defend the weak against the powerful. "I didn't become a Democrat because I was angry," he writes. "I'm a Democrat because I received a good education in the public schools of Anoka, Minnesota, and attended a great university and when I was 18, John F. Kennedy ran for president."

This is my story! I attended excellent public schools in Iowa City, Iowa. I attended a great university, the University of Iowa. And, much to the ire of my Republican grandfather, I voted for John F. Kennedy for president. Like Keillor I worked to put myself through college. I discovered classical music, lecture halls, libraries, concerts, plays, opera, modern art, jazz, Dave Brubeck, great books, Sociology, classic literature, professors who cared about teaching, all- 
night cafes, coffee shops, existentialism, Marxism, Sartre, Camus, Hemingway, C. Wright Mills, folk music, the civil rights and anti-war movements.

I paid $\$ 93$ for a semester's tuition and soon found my way to the long reading tables in the University Library. Around me, as there were for Keillor, were young men and women like myself, "bent to the hard work of scholarship, folks for whom attending college was not an assumed privilege" (Keillor 2004: 63). We dressed alike, ate the same food, listened to the same juke box music in the small cafes. We'd come early, before 7:00 p.m., to get a good table, my friends and I. And there we would sit, books stacked in front of us, sharpened pencils, heads bowed, "rows and rows of us, reading, reading, reading-sons of garage mechanics on their way to medical school, daughters of dairy farmers out to become professors of Romance languages” (Keillor 2004: 63-64).

In the Music Room in the Iowa Memorial Union I discovered Ravel's "Bolero" and learned how to smoke a pipe and look existential, and read philosophy. There I sat, in my favorite chair, lost in the music, looking to others to see how to do this. We had a purpose, a sense of vocation, we could have stepped out of Thomas Hart Benton's great mural, "The Children of the Great Plains Claiming Their Birthright" (Keillor 2004: 64). We were "taking our oncein-a lifetime chance to realize our God-given talent...no guarantees of success" (Keillor 2004: 64-65), hard work, a love of this life, reading, reading, reading, reading.

I moved back into this space as I turned the pages of Homegrown Democrat. I shared my warm feelings of nostalgia with Aisha Durham, who reminded me that this sounded a lot like a white man's story about college in the 1950s. She asked, "Were there any African-Americans in that music room?"

Stunned, I searched back in my memory. There were no African-Americans in Iowa City, well, one family. There was a black man on the basketball team for a while but they sent him back to New York City for gambling. Aisha was right.

I went back to Keillor to see what he said about race. Democrats, he states, "have changed American in simple basic ways in the past fifty years that have benefited everyone. Race has become less and less an issue in people's lives and racism has ceased to be socially acceptable anywhere. Women have moved into every realm of society... Equal opportunity in education, employment, housing...Homegrown Democrats led the way in bringing these things about" (Keillor 2004: 26). Indeed!

I can't let these lines stand without protest. In my community racism is on the rise. We have more, not less discrimination. Hate crimes are a daily occurrence. Women have hit glass ceilings, and the community drove our last Chancellor out of town. They said she was insensitive to local tradition. Maybe we don't have the right kind of Democrats in Urbana. I doubt it.

In the chapter "The Good Democrat" he lists ten characteristics of Democrats. Democrats distrust privilege and power (Keillor 2004: 169); regard equality as bedrock (Keillor 2004: 172); are inclusive and integrationist to the core (Keillor 2004: 174); are city people at heart...The city is the crowning achievement of society (Keillor 2004: 176); believe in individualism (Keillor 2004: 180); are union guys (Keillor 2004: 182); have sympathy for the helpless, especially children and the elderly (Keillor 2004: 185); are diehard teachers (Keillor 2004: 189); are realists (Keillor 2004: 192); have values that are rooted in courtesy and kindness (Keillor 2004: 195). The good Democrat is homegrown, from the great Midwestern heartland, the land of Lake Wobegons.

The last chapter invokes $9 / 11$, reading it as a rare moment of shared community, pain and suffering in New York City. Anticipating the Republican National Convention, which celebrated Bush and 9/11, Keillor invokes the men and women who died that day, "They deserve better than to be the platform for intolerance" (Keillor 2004: 232). He catches himself. "I refuse to be furious. I am a happy Democrat living in a great country, at home in St. Paul, Minnesota, where no matter what, there is a lot of satisfaction going on a good deal of the time" (Keillor 2004: 233).

I'm an angry Democrat. I'm angry at the Democrats who supported Bush's war. I'm angry at politicians who wait to see which the wind is blowing before they commit a political act requiring honesty and courage. I'm tired of Democrats who make lists. I'm angry at Democrats who think the good Democrat is homegrown. I'm not sure homegrown works any longer. My homegrown was narrow and provincial, and white. In my Lake Wobegon the Golden Rule and the politics of kindness and the obligation to defend the weak and the poor only extended to those folks like the rest of us.

I agree we have a moral obligation to bequeath this world to our grandchildren in better shape than we found 
it. But it is not just our grandchildren to whom this world is bequeathed. This is a global project. I know it must be local, but I do not think it can be entirely built from the values that circulate in Keillor's imaginary utopia. And this saddens me because for a long time I time I have liked going to Lake Wobegon at the end of a hard week. I'm not so sure I can any longer do this. I must look elsewhere for my alternative model of democracy.

Urbana Illinois, 20 September 2004

\section{References}

Baudrillard, Jean. 1983. Simulations. New York: Semiotext (3). Corn, David. 2003. The Lies of George W. Bush: Mastering the Politics of Deception. New York: Crown Publishers.

Dowd, Maureen. 2004. Bushworld.: Enter at your Own Risk. New York: G. P. Putnam's Sons.

Hersh, Seymour M. 2004. Chain of Command: The Road from 9/11 to Abu Ghraib. New York: HarperCollins.

Ivins, Molly with Lou Dubose. 2003. Bushwacked: Life in Geroge W. Bush's America. New York: Random House.

Keillor, Garrison. 2004. Homegrown Democrat: A Few Plain thoughts for the Heart of America. New York: Viking.
Moore, Michael. 2003. Dude, Where's My Country. New York: Warner Books.

Pope, Carl. 2003. "Big Pigs at the Trough: The Worst Agriculture Policy Money Can Buy." Sierra, 88, 8 (November, December): 8-9.

Powers, Thomas. 2003. "The Vanishing Case for War." The New York Review of Books, 50, 19 (4 December): 12-17.

Roy, Arundhati. 2004. An Ordinary Persons Guide to Empire. Cambridge, Mass.: South End Press.

Woodward, Bob. 2004. Plan of Attack. New York: Simon \& Schuster. 